Published in final edited form as:

Front Biosci (Schol Ed). ; 2: 993-1008.

\title{
Stem cells as potential therapeutic targets for inflammatory bowel disease
}

\author{
Udai P. Singh ${ }^{1}$, Narendra P. Singh ${ }^{1}$, Balwan Singh ${ }^{2}$, Manoj K. Mishra ${ }^{3}$, Mitzi Nagarkatti ${ }^{1}$, \\ Prakash S. Nagarkatti ${ }^{1}$, and Shree Ram Singh ${ }^{4}$ \\ ${ }^{1}$ Pathology and Microbiology and Immunology, School of Medicine, University of South Carolina, \\ Columbia, SC 29208 \\ ${ }^{2}$ Primate Research Center, Emory University, Atlanta GA 30329 \\ ${ }^{3}$ Department of Math and Science, Alabama State University, Montgomery, AL 36101 \\ ${ }^{4}$ Mouse Cancer Genetics Program, National Cancer Institute, Frederick, MD 21702
}

\begin{abstract}
The rates of incidence and prevalence of Crohn's disease and ulcerative colitis, the two major forms of inflammatory bowel disease (IBD), are rising. Estimates indicate $>1$ million new cases of IBD in the United States annually. The conventional therapies available for IBD range from antiinflammatory drugs to immunosuppressive agents, but these therapies generally fail to achieve satisfactory results due to their side effects. Interest in a new therapeutic option, that is, biological therapy, has gained much momentum recently due to its focus on different stages of the inflammatory process. Stem cell (SC) research has become a new direction for IBD therapy due to our recent understanding of cell populations involved in the pathogenic process. To this end, hematopoietic and mesenchymal stem cells are receiving more attention from IBD investigators. The intestinal environment, with its crypts and niches, supports incoming embryonic and hematopoietic stem cells and allows them to engraft and differentiate. The above findings suggest that, in the future, SC-based therapy will be a promising alternative to conventional therapy for IBD. In this review, we discuss $\mathrm{SCs}$ as potential therapeutic targets for future treatment of IBD.
\end{abstract}

\section{Keywords}

Inflammatory bowel disease; Crohn's disease; Ulcerative Colitis; Stem cells; Review

\section{INTRODUCTION}

Inflammatory bowel disease is an autoimmune disease associated with uncontrolled innate and adaptive immunity. IBD is defined by an inflammation of the gastrointestinal tract, associated with unrestrained immune response with increased abnormal T cell activity. This is the central feature of this disease. Based on clinical features and histopathology, IBD encompasses at least in two forms, ulcerative colitis (UC) and Crohn's disease (CD). UC is a superficial ulcerative disease affecting the colon, whereas $\mathrm{CD}$ is a transmural disorder involving the entire gastrointestinal tract, from the mouth to the anus (Figure.1A, B) (1). Both forms of IBD can increase the incidence of gastrointestinal and colon cancers, and both are associated with significant morbidity and mortality worldwide. In addition, both can begin early in life and

Send correspondence to: Shree Ram Singh, Mouse Cancer Genetics Program, National Cancer Institute, Frederick, MD 21702, Tel: 301-846-7331, Fax: 301-846-7017, singhshr@ mail.nih.gov. 
persist for long periods. There are significantly more cases reported in Western countries than in other parts of the world. Estimates indicate more than 1 million new cases of IBD in the United States annually, with 50\% involving UC and 50\% involving CD (1-7). IBD represents a significant burden in the US, resulting in over 700,000 doctor's visits and 100,000 hospitalizations per year at a cost of $\$ 1.8$ billion annually (7-9). The increased frequency of IBD observed consistently in the industrialized world may be linked to changes in the gastrointestinal microbiota that affect the immune system and influence the risk of IBD. The pathogenesis of IBD is complex and multifactorial. The exact causes of IBD remain unclear, but the infiltration of leukocytes, such as neutrophils, monocytes, and lymphocytes, into the intestinal mucosa is believed to be critical in the formation of mucosal lesions via increased production of proinflammatory cytokines and via inflammatory mediators $(10,11)$. Familial clustering of IBD and higher concordance rates in monozygotic twins than dizygotic twins, particularly of CD, points to the importance of genes in IBD (12). Further, epidemiological, molecular, and recent genome-wide association studies collectively suggest that IBD is a polygenic disease. There are more than 50 confirmed IBD-associated genes (13). It has been shown that genetic susceptibility to IBD in humans is associated with variations in genes that encode proteins relevant to both innate and adaptive immunity, including $I L 23 R, I L 12 B$, NKX2-3, BSN, TLR4, CCNY, JAK2, and STAT3 (14-16). Several genes involved in different aspects of bacterial handling are defective only in $\mathrm{CD}$, including NOD2 and the autophagy genes ATG16L1 and IRGM (13, 16-18). The genes HERC2, STAT3, and PTPN2 and two DRB1 alleles in the $\mathrm{MHC}$ region are associated only with UC (18). However, the cumulative evidence suggests that genetic, environmental, microbial, and immunological factors contribute to development of IBD (19-40). It is believed that in CD, the cellular response, with increased activation of $\mathrm{CD}^{+} \mathrm{T}$ cells mostly differentiated into a $\mathrm{T}$ helper type 1 (Th1) subpopulation, increases the amount of cytokines, which has a significant impact on the course of disease progression. The severe and continuous inflammation is able to disrupt the intrinsic repair system, leading to refractory ulcers in the gut. Treatment is sometimes effective for mild cases of IBD, but for the most severe cases, treatment options are very limited.

Advances in the understanding of the cell populations involved in pathogenic processes and recent findings on the regenerative and immunoregulatory potential of SCs have opened up a new direction for IBD therapy. SCs hold promise for treatment in a variety of degenerative diseases and cancers (41-44). In the present review, we will discuss the current findings for IBD therapy, including SC-based therapies.

\section{CLINICAL FEATURES AND NATURAL HISTORY OF IBD}

The clinical and pathological features of IBD depend on the genetic background and alteration of immunoregulatory molecules in the host (19-40). These factorial conditions support the current belief that different and independent alterations cause IBD and that UC and CD are heterogeneous disorders with multiple pathogenic mechanisms. The inflammatory process in UC is confined to the mucosa and superficial sub-mucosa of the large bowel, and the histopathological features of UC account for the symptom of bloody diarrhea. Nonetheless, a small number of patients with UC suffer from constipation, even during heightened episodes of disease activity. The severity of this disease is generally proportional to the extent of bowel involvement and the intensity of inflammation. IBD symptoms that may occur in UC patients include fever, vomiting, perianal disease, fistulas, rectal bleeding, weight loss, and anorexia (16-18).

CD usually presents with diarrhea, abdominal pain, and/or weight loss; $\mathrm{CD}$ exhibits a complex inflammatory process and is more variable in its clinical manifestation than UC. The illness characteristically waxes, wanes, and is not diagnosed for many years. Active disease is characterized by leukocyte infiltration in which macrophages and lymphocytes predominate. 
In $\mathrm{CD}$, transmural involvement is common; aphthoid ulcers can be seen overlying dense areas of lymphoid tissues. The aggregation of macrophages leads to the development of noncaseating granulomas in about 50\% of patients. Collagen deposition is common and may contribute to the formation of strictures. These inflammatory processes in CD can extend beyond the gastrointestinal tract, e.g., formation of fistulas. Fistulas can be either external (enterocutaneous or perianal) or internal. The estimated incidence of fistulas in patients with CD is about $35 \%(16-18,45)$. Perianal disease and fistulas can lead to fecal incontinence, abscess formation, and anal strictures. The diverse sites of tissue involvement and varying extent of inflammation cause a wide spectrum of clinical manifestations. For example, several mechanisms can contribute to diarrhea, including partial bowel obstruction, mucosal destruction, malabsorption of bile salts, bacterial overgrowth, rapid transit of fistulas, and the secretory effects of inflammatory mediators. Furthermore, patients with long-standing, advanced IBD are at risk for colorectal cancer and should undergo regular colonoscopies, biopsies, and follow-up care. The distinguishing features of $\mathrm{CD}$ and $\mathrm{UC}$ with respect to pathology, complications, risk factors, and histology are summarized in Table 1 (19-40).

\section{CELLULAR AND MOLECULAR MECHANISMS OF IBD}

IBD may be the result of enhanced abnormalities of the immune system and normal gut flora (46) or an overall autoimmune deregulation and imbalance of helper T cells (47-51). The intestinal mucosa is normally maintained in a state of balanced inflammation in which there is equilibrium between protective immunity and tolerance to self-antigen and commensal bacteria. Regulatory T lymphocytes (Tregs) are known to play an important role in limiting inflammation in response to nonpathogenic antigens, and defects in this subset of T cells have been implicated in the pathogenesis of IBD $(35,52)$. It is still unclear whether the immune system is deregulated due to an intrinsic defect or due to continued stimulation resulting from a change in the epithelial mucosal barrier. Penetration of bacteria through the mucosal barrier may be the cause of immune stimulation that results in direct interaction between dendritic cells and lymphocyte populations that can promote a classic adaptive immune response. Alternatively, the bacterial population may stimulate the surface epithelium, possibly through receptors that are components of the innate immune response system. As a result, the epithelium produces cytokines and chemokines, both of which recruit and activate mucosal immune cells (Figure. 2). Activation of antigen-presenting cells (APCs), such as dendritic cells, or direct stimulation promotes the differentiation of Th1 in patients with $\mathrm{CD}$ or, possibly, $\mathrm{T}$ helper type 2 (Th2) cells, which are associated primarily with UC (Figure. 2).

It has been suggested that $\mathrm{CD}$ is Th1-mediated process in which IL-23 is overproduced by lamina propria (LP), macrophages and $\mathrm{T}$ cells (53-56). There is a consensus that the mucosa of CD patients is dominated by Th1 cell producing inflammatory cytokines $(46,47,49)$. Considerable data also support the alternative etiologic hypothesis that a poorly regulated immune response to antigens present in the gut lumen of IBD patients drives this disease $(46,47,49,52,57)$. Substantial progress has been made in characterizing the immune cell population and extent of inflammation in patients with IBD as well as in murine models. There is reasonable consensus that the mucosa of patients with established $\mathrm{CD}$ is dominated by $\mathrm{CD} 4^{+}$lymphocytes with a Th1 phenotype that is characterized by the production of IFN-gamma by LPT cells and IL12 by LP macrophages. In contrast, it is possible that the mucosa of patients with $\mathrm{UC}$ is dominated by $\mathrm{CD} 4^{+}$lymphocytes with a Th2 phenotype characterized by the production of transforming growth factor (TGF)-beta, IL5 and IL13 $(54,58)$. Nevertheless, both CD and UC share critical end-stage pathways, as shown by the enhanced production of IL21 and IL23 in both disorders $(59,60)$. Hence, the two major forms of IBD are the result of poorly regulated or excessive $\mathrm{T}$ helper responses. It is likely that these inappropriate $\mathrm{T}$ cell responses to antigenic components of the intestinal microflora result in dysfunctional mucosal immunity (or tolerance) that normally drives (or regulates) responses to microbial flora 
(61-63). However, it has recently been found that IL23-driven Th17 cells also play an important role in chronic IBD (64). Additionally, Th17 cell-associated cytokines, surface molecules, and transcription factors (IL6, IL17, IL23R, IRF4, STAT3, and RORA) were increased in CD4+ $\mathrm{T}$ cells isolated from patients with both CD and UC $(64,65)$. Furthermore, a local increase in special CD14 ${ }^{+} \mathrm{CD} 209^{+}$macrophages in the intestine has been found in CD (66). The CD14 ${ }^{+}$ macrophages in CD produce excessive IL23 in response to exposure to enteric bacteria, and the IL23 acts on T cells and natural killer (NK) cells that promote IFN-gamma production.

\section{WHY IBD NEEDS BIOLOGICAL THERAPY}

While the causes of human IBD remain unknown, the two major forms are defined by their clinical, pathologic, radiologic, and endoscopic characteristics (1). Recent clinical observations suggest that genetic factors significantly contribute to IBD susceptibility. There are wide variations in the incidence and prevalence of $\mathrm{CD}$ and $\mathrm{UC}$ among different populations. Multiple studies suggest that the absolute risk of IBD is approximately $7 \%$ among first-degree family members (67).The conventional therapy for IBD quite commonly fails to produce satisfactory results. Moreover, conventional therapy involves many side effects, which turn into more complications at later stages of the disease. Several biological therapies have been developed for treatment of CD, including adalimumab, infliximab, and certolizumab pegol; each of these antagonizes TNF-alpha and has been shown to decrease the clinical severity of the disease. Below we will discuss the currently available biological therapies, their drawbacks, and SC transplantation therapy for IBD.

\subsection{Currently available treatments}

Conventional therapy employs the most benign drugs first, adding drugs with more potential side effects later. The diagnosis of IBD is based on a comprehensive analysis of an individual's clinical history; physical findings; endoscopic, radiologic, and histological features; and the results of routine laboratory tests. Fortunately, an expanding number and variety of drugs that target the inflammatory process, either broadly or selectively, are effective in controlling IBD and in sustaining symptomatic remission for prolonged periods. However, these immunomodulatory drugs are expensive and frequently toxic. Furthermore, they are not effective in all patients; many patients suffer from recurrence of IBD, underscoring the need for improved treatments. The currently available treatments are listed in Table 2.

The IBD treatments currently available to clinicians include 5-aminosalicylates, sulfasalazine, antimicrobial therapy, corticosteroids, immunosuppressive agents, and monoclonal antibodies (mAbs). There are few commercially available mAbs, which include natalizumab, which is a $\mathrm{mAb}$ directed against alpha4-integrin, and the three antitumor necrosis factor (TNF) antibodies, namely, infliximab, adalimumab, and certolizumab pegol (68-71). The 5-aminosalicylatebased compounds have remained a mainstream first line of treatment for IBD patients. Early studies have shown that 5 -aminosalicylate was the functionally active moiety of this prototypical sulfasalazine congener. 5-aminosalicylate can block the production of prostaglandins and leukotrienes, inhibits the bacterial peptide-induced neutrophil chemotaxis, scavenges the reactive oxygen metabolites, and inhibits the activation of nuclear factor-kappa B. However, recent evidence suggests that this agent is ineffective, and routine use is not recommended (72). Corticosteroids have been commonly used when 5-aminosalicylate-based compounds were deemed inadequate. Topical corticosteroids, including prednisone and prednisolone, have been used for moderate to severe UC and CD and are highly effective. Azathioprine and its active metabolite, 6-mercaptopurine, have been extensively used when corticosteroids are not tolerated or useful Methotrexate and cyclosporine are also effective treatments for both UC and CD $(73,74)$. Recently, a randomized, double-blinded, placebocontrolled trial was done using ciprofloxacin and metronidazole for treatment of perianal fistulas in patients with $\mathrm{CD}$ (75). This study suggested that remission and response occurred 
more often in patients treated with ciprofloxacin, but the differences were not significant (75). The precise mechanism of action responsible for the therapeutic effect of these drugs on IBD remains elusive. However, there is a consensus that the drugs act by suppressing the activation and generation of specific and long-lived T helper cells; this suppression might account for the prolonged time needed to achieve a therapeutic response and the recurring/ relapsing nature of this disease.

The availability of the prototypical anti-TNF-alpha antibody agent, infliximab, has offered an important advance in the therapy for $\mathrm{CD}(68,76)$. Its effectiveness suggests that TNF-alpha may play a pivotal role in IBD (77). Infliximab is a genetically engineered immunoglobulin subclass G1 (IgG1) murine-human chimeric monoclonal antibody containing about $75 \%$ human protein and 25\% murine protein. TNF-alpha is a proinflammatory cytokine, produced by leukocytes, and is involved at local sites of inflammation and activation of granulocytes and fibroblasts during CD. TNF-alpha is also involved in the development of colitis in many murine models of colitis. Indeed, TNF-alpha levels are elevated in tissues and secretory fluids produced by mucosal cells of the LP (78-80). While TNF-alpha produced by CD4 ${ }^{+} \mathrm{T}$ cells is neither necessary nor sufficient for induction of murine colitis, its production by APCs is essential for the histopathological and clinical signs of colitis (81). It has also been shown that anti-IFN-gamma antibody treatment and administration of anti-TNF-alpha antibody or of soluble TNF-alpha receptor significantly attenuate colitis development in IL-10 $0^{-/-}$mice (82). The newest immunosuppressive agent with proven efficacy in CD treatment, the anti-alpha4 integrin IgG4 antibody natalizumab, has been efficacious in patients in whom anti-TNF therapy was ineffective (83). It has been reported that visilizumab, a humanized IgG2 mAb against the CD3-epsilon chain of the T-cell receptor, may inhibit the inflammatory response in IBD by inducing apoptosis of activated $\mathrm{T}$ cells and may have other diverse immunomodulatory and chemotactic properties (84).

Several other therapeutic approaches have been used to inhibit Th1 polarization in hosts with colitis; these approaches include monoclonal antibodies against IL12, IFN-gamma, IL18, and IL2 receptors, as well as against immunomodulatory recombinant human protein IL10. It is established that IL12 drives Th1 differentiation and subsequent IFN-gamma production (85). Clearly, IL12, IL23, and IFN-gamma play a critical role in the induction and progression of colitis $(54,86-88)$. Administration of IL10 to IL $10^{-/-}$mice weanlings completely prevented colitis; however, this treatment produced only a modest improvement in mice with established colitis (89). Anti-IL18 and anti-IL12 receptor antibodies may also used for therapeutic benefit. It has been shown that p40 antibodies ABT874 and ustekinumab (CNTO1275) were effective in inducing response or remission in patients with $\mathrm{CD}$, and reducing the production of IL12, IL23, TNF and IFN-gamma from lamina propria mononuclear cells $(90,91)$. Further, in a mouse T cell mediated colitis model, anti-IL23 monoclonal antibody reverses active colitis (92). The increased production of IL17 in cases of dextran sodium sulfate (DSS) colitis and in cases of trinitrobenzene sulfonic acid (TNBS) colitis has been reported (93). Further, attenuation of DSS colitis in IL17-deficient mice (94) and suppression of the development of DSS colitis have been reported in inhibition experiments with IL17-neutralizing antibody (95). Inhibition of the Th17 pathway may be a promising option for IBD treatment.

Currently in development are several new biological and pharmaceutical therapeutics that target $\mathrm{T}$ helper cell differentiation pathways, adhesion molecules, TNF-alpha, leukocyte activation and, most recently, the CXCR3 axis $(29,96,97)$. It has been shown that anti-CD3 antibody can be used to treat UC by producing accumulation of IL10-expressing FoxP3- $(\operatorname{Tr} 1)$ cells in the small intestine and IL10-expressing FoxP3 ${ }^{+} \mathrm{T}$ cells in the colonic LP $(96,98)$. It has recently been postulated that following anti-CD3 therapy, ingestion of apoptotic T cells by macrophages and immature dendritic cells results in production of TGF-beta and that this may be responsible for the observed generation of Tregs following therapy (99). Further, inhibitors 
of histone/protein deacetylase (HDACs), which are expressed in FoxP3 ${ }^{+}$Tregs and in HDAC9deficient mice, have recently been demonstrated to improve Treg function and increase Treg numbers, and as a result, the mice are less susceptible to DSS colitis (97). There are several other known molecular targets, including the IL2 receptor (targeted by daclizumab and basiliximab) in UC, the costimulatory molecule CD28 (targeted by the CD152 fusion protein abatacept) in both $\mathrm{CD}$ and $\mathrm{UC}$, mitogen-activated protein kinases in $\mathrm{CD}$, and the $\mathrm{B}$ cell marker CD20 (targeted by rituximab) in both CD and UC (100).

\section{ANIMAL MODELS OF IBD}

In recent years, animal models have been very useful in elucidating the complex interaction between genetic and environmental factors that lead to IBD. They can provide fundamental insights into the importance of immunologic deregulation and intestinal microbiota (22). One of the earliest murine models developed for the study of IBD involves the use of TNBS, which is delivered by enema to induce Th1-mediated and CD40-dependent colitis (101). Another mouse model for IBD involves the spontaneous development of chronic inflammation in T cell receptor-alpha knockout (TCR-alpha ${ }^{-/-}$), TCRbeta $^{-/-}$, TCRbeta $^{-/-}$x TCR $\delta^{-/-}$and $\mathrm{MHC}^{-/-}$mice (102). Additionally, transfer of $\mathrm{CD}^{4} 5 \mathrm{RB}^{\mathrm{Hi}} \mathrm{T}$ cells to severe-combined immuno-deficient (SCID) mice results in the development of murine colitis that is similar to human CD (103). Co-transfer of $\mathrm{CD} 45 \mathrm{RB}^{\mathrm{Hi}}$ with $\mathrm{CD} 45 \mathrm{RB}^{\mathrm{Lo}}$ cells blocked IBD development. IL2 ${ }^{-/-}$(50) or IL10 $0^{-/}$mice (48) develop spontaneous colitis without a single cytokine. Senescenceaccelerated mice (SAMP1/Yit) have been shown to spontaneously develop colitis that is similar to human CD (104). In both IL-10-/- and SAMP1/Yit mouse models of CD, Th1 cytokines (TNF-alpha, IL12, and IFN-gamma) mediate intestinal inflammation $(105,106)$. These experimental strategies have resulted in a consensus that increased levels of IL12, a cytokine known to drive Th1 differentiation and IFN-gamma production $(85,107)$, is positively correlated with the promotion of colitis in CD models. Knocking out the gene encoding IL10, a negative regulator of IL12, leads to an increased level of IL12 (106) as well as manifestation of CD-like symptoms. There is much evidence that neutralizing antibodies against IL12 in animal models of CD produces a significant reduction in mucosal inflammation $(87,88)$, suggesting that both IL12 and IFN-gamma play pivotal roles in the pathogenesis of CD. These studies indicate that the symptoms in the IL10 knockout mice model are very similar to human CD symptoms and that therefore this particular model will be a good model for any biological or SC therapy. Recent reports suggest that glucagon-like peptide-2 (GLP-2), a member of a family of glucagon-like peptides that is synthesized in the enteroendocrine cells of the small intestine and colon and signals through a G-protein coupled receptor (GLP-2R), has been shown to reduce intestinal damage in animal models of small intestinal and colon cancers (108). Use of GLP-2 for IBD treatment is restricted by the activity of a serine protease, dipeptidyl peptidase (DP) IV (109). Further, it has been found that inhibition of DP activity alone using isoleucyl-cyanopyrrolidine (P59/99) or isoleucyl-thiazolidine (P32/98) can significantly reduce disease activity in the DSS colitis model (110). These findings may lead to the development of new IBD treatment strategies centered on inhibition of DP activity.

Experiments using two independent, noncomplementing strains of mutant mice with reduced epithelial barriers have shown that these mouse models develop spontaneous colitis (111). Both strains had a missense mutation in the $M u c 2$ gene. Mutant $M u c 2$ shows abnormal oligomerization, leading to an endoplasmic reticulum (ER) stress response in goblet cells that results in reduced mucus secretion and concurrent elevation of lamina propria proinflammatory cytokine levels; this finding suggests that genetic alterations in UC patients may have led to ER stress and aberrant mucin assembly (111). Further, in a model of immune deregulation, it has been demonstrated that genetic predisposition to IBD is caused by the interaction of several genes (111). Kang et al. (112) generated a mouse line with defective IL10 signaling and defective TGF- $ß$ signaling in T cells and found that these mice developed a fulminant UC-like 
disease that was ameliorated by anti-cytokine therapy. Recent studies have also focused on the potential link between chronic inflammation and the process of angiogenesis in the search for potential IBD therapeutic options (113). Using an animal IBD model, it has been shown that hepatocyte growth factor (HGF) can substantially ameliorate the gross and microscopic progression of IBD and may stimulate nonpathologic angiogenesis in IBD (114). Further, it has been found that clinical administration of HGF could be beneficial in the treatment of IBD either alone or in combination with immune modulators and anti-angiogenic medications that reduce pathologic angiogenesis (114).

\section{STEM CELL THERAPY FOR IBD}

In IBD, both damaged intestinal tissue and the immune system need to be repaired. Only SC therapy can simultaneously repair the damaged intestinal tissue and correct immunological abnormalities. SCs are essential for maintaining the integrity of almost all adult tissues. The precisely planned and controlled differentiation of adult SCs has great therapeutic potential for tissue regeneration and treatment of many degenerative diseases. Embryonic stem cells (ESCs) have pluripotent potential and can differentiate into intestinal epithelium as well as immune cells. This dual capacity may allow SCs to restore the intestinal epithelium as well as the immune balance in mice with colitis, allowing investigation of protocols that could be effective in humans. The mammalian small intestine provides an elegant system for studying aspects of SC biology, such as control of proliferation and differentiation. The murine intestine is lined with an epithelial monolayer that is folded to form crypt and villus structures; these two types of structures are both physically and functionally distinct. The epithelia of the small intestine and colon are the most rapidly proliferating tissues in adult mammals. The epithelium is renewed every 3-5 days by SCs residing in the base of each crypt. The SCs first generate the rapidly cycling transit-amplifying (TA) cells, which divide every $12-16 \mathrm{hrs}$ and generate about 300 cells per crypt per day. When the TA cells reach the crypt-villus junction, they rapidly differentiate into the four terminally differentiated (TD) cell types in the mucosa (115). These cell types are goblet, enteroendocrine, enterocyte, and Paneth cells. Paneth cells reside for about 20 days at the crypt base and are the only differentiated cells that escape the upward migration (116). The rest of the epithelial lineages migrate upward from the crypt to the tips of adjacent villi, where they are extruded $(116,117)$. The entire intestinal epithelium is renewed every three days in mice (five days in humans); this length of time corresponds to the time needed for a differentiated cell to travel the distance between the base and the top of a villus, where about 1400 cells are exfoliated per day. These events establish a SC hierarchy in which SCs with maximum pluripotency and proliferating potential reside in the SC zone near the crypt base (116-118). The villus architecture is assumed to provide an optimal SC niche for SCs to migrate, proliferate, and differentiate. It has already been reported that SC-niche interactions are essential for SC proliferation and differentiation $(116,117,119)$. The bone marrow derivation of pericryptal myofibroblasts in murine and human small intestine and colon was recently demonstrated (120). In IBD, SCs could be used for therapy of incoming SCs respond to factors and cytokines released from damaged tissue, home to the injury site, and differentiate into epithelial cells and lymphocytes to modulate tissue damage and immune response..

Due to advances in our understanding of the cell populations involved in the pathogenic process and recent findings on the regenerative, trophic, and immunoregulatory potential of SCs, hematopoietic (HSC) and mesenchymal stem cells (MSCs) have captured the attention of IBD investigators. There has been much progress due to a number of case reports; the hope is that the steps used in in vitro and in vivo models can be used to transfer the SC-based approach directly to human patients. Further, the immunosuppressive action of SCs would be very convenient in future clinical applications of these cells in IBD. SC-based studies could 
ultimately lead to the development of novel drugs that can cure IBD and can reduce the risk of IBD-associated complications.

MSCs play a central role in coordinating events related to repair of epithelium damaged by inflammatory processes. MSCs can be isolated from any of the connective tissues, including bone marrow and adipose tissue. The repair process can usually restore normal intestinal architecture in UC patients, but this is difficult in CD patients due to excessive fibrosis leading to formation of strictures and obstructions. Fibrosis in CD is associated with mesenchymal cell persistence and hyperplasia, tissue disorganization, and collagen deposition. Recently, it has been reported that mesenchymal cells derived from bone marrow SCs may play an important role in repairing fibrosis (120). The mesenchymal cells (intestinal subepithelial myofibroblasts) regulate proliferation and differentiation of the epithelial cell basement membrane, as well as extracellular matrix metabolism (121). These cells also cooperate in sensing pathogens and actively participate in immune responses and in the induction of tolerance $(122,123)$.

Inflammatory cytokines and growth factors, such as TGF-beta, IGF-1, and EGF, control the expression of matrix metalloproteinase (MMP) and of tissue inhibitors of metalloproteinases (TIMPs) in these cells and have been shown to be elevated in the inflamed mucosa of IBD patients (124). In inflamed IBD tissues, the expression of MMP-1-3 and 9 is increased relative to that of TIMP-1 and 2. The MSCs control the mucosal repair process by extracellular matrix manipulation and release of cytokine and growth factors. The repair process involves restitution in response to minor to moderate injury when the basement membrane remains intact. It is not known how the balance between MMPs and TIMPs is maintained. However, it has been demonstrated that blocking TGF-beta1 in cultures of intestinal biopsies may upregulate the expression of MMP-3, but not of TIMP-1, suggesting that TGF-beta1 may also play a critical role in IBD tissue remodeling (125). The MSCs accelerate the proliferation and migration of residual epithelial cells over denuded areas by releasing TGF-beta, EGF, bFGF, and various inflammatory cytokines. In response to deep tissue injury, MSCs proliferate to form a new basement membrane over the epithelial cells and then proliferate and migrate to repair all epithelial tissues (Figure. 2). It has also been demonstrated that MSCs have the ability to nonspecifically modulate the immune response through their antigen-presenting abilities and through the suppression of dendritic cell maturation (126). In addition, MSCs significantly ameliorated the clinical and histopathological severity of colitis by decreasing the level of inflammatory cytokines and increasing the level of IL10 (127). It has been demonstrated that human adult stem cells (hASCs) derived from adipose tissue have the capacity to suppress acute inflammatory autoimmune responses in mice by inhibiting inflammatory and Th1 responses by increasing IL10 secretion; thus, these cells have emerged as attractive candidates for cell-based IBD treatments (127). MSCs can modulate the innate immune response, inhibit dendritic cell differentiation and maturation, act on resting NK cells, and decrease the respiratory burst and apoptosis of neutrophils. MSCs have been shown to trigger generation of Tregs and to directly induce antigen-dependent Treg proliferation $(128,129,130)$. Further, Lanzoni et al (130) reported that MSC can be isolated from intestinal mucosal tissues are able to perform trophic and immunomodulatory functions. These works suggest that MSC may serve as a candidate therapy for patients who have failed to respond to biological therapy.

HSCs are multipotent and are able to restore the entire hematopoietic compartment after myeloablation. HSCs can be obtained in large quantities and have been used clinically for years. Trans-differentiation of HSCs into other cell types remains in question, but it is increasingly apparent that HSCs can form endothelial precursors and therefore may be an optimal source of SCs for intestinal repair (131). It has been shown that donor cells from human bone marrow transplants were present in many recipients' tissues (132). HSCs possess migratory capacity; these cells migrate directly to the injury site and differentiate into the epithelial and immunomodulatory elements that are unique to the intestinal compartments, 
leading to tissue recovery and restoration of the normal mucosal system (133). The potential of HSCs in the treatment of IBD is currently being analyzed in clinical trials.

ESCs have the potential to give rise to any of the hundreds of cell types in the human body, raising exciting new prospects for biomedical research and for regenerative medicine. ESCs are the subject of a significant area of research with promise for the future treatment of inflammatory disease. The unique pluripotent ability of ESCs has drawn many scientists to utilize ESCs to study the mechanisms by which congenital or acquired diseases occur (134). The ability to generate clinically relevant numbers of defined cell populations has provided us with the basic elements for tissue repair and regeneration. Although most scientists agree on the potential of ESCs, it has also become clear that pluripotency is a double-edged sword; the same plasticity that permits ESCs to generate hundreds of different cell types also makes them difficult to control. It has been reported that ESCs ameliorated piroxicam-induced colitis in IL10/- mice (135); this study has shown that in vitro pre-differentiated ESCs migrated and homed exclusively to the colon, small intestine, and the liver; engrafted for the long term; reduced inflammation and tissue damage; and restored immune balance (135). More recently, it has been found that gingival-derived MSCs (GMSCs), isolated from human gingival, can function as an immunomodulatory and anti-inflammatory component of the immune system in vivo, and could be a promising source for cell based therapy in experimental IBD (136).

\subsection{HSC transplantation advances in cell therapy}

The long-term management of IBD depends on the intensity of disease, location, endoscopic severity, clinical manifestations, and complications due to other forms of disease. Many cellular and molecular pathological pathways have previously been identified as therapy targets (72). The available therapies do not produce responses in all patients, and non-responding patients are frequently forced to pursue a surgical option, although surgical intervention still will not resolve the disease (72). Because there are currently no curative options, an approach based on SCs could drive major changes in disease management and treatment. It is well known that impairment of the control of intestinal immune cell function and turnover plays a central role in the deregulated and protracted inflammatory response in IBD. A high-dose immune ablation regimen might allow detrimental T-lymphocytes to be eliminated, and after HSC transplantation, hematopoiesis might generate naïve cells that can restore tolerance. Patients receiving HSCs are in the process of an immune system reboot. The HSC-transplanted patients probably experience an autoreactive response, and the immune system is almost completely replaced. Although the susceptibility to relapse of CD is eliminated, IBD patients may remain in permanent remission if they are not exposed to the appropriate trigger in the future. Based on these concepts of IBD therapy, several cases have been reported to show long-lasting remission in IBD patients.

The first case of CD regression after autologous HSC transplantation for hematopoietic malignancy was reported in 1993 (137). Since then, more cases have been reported, and in 1996, one UC patient and two CD patients treated for coincidental malignancies experienced remission from IBD after high-dose chemotherapy and autologous HSCs (138). After these reports, a large number of CD patients undergoing allogeneic transplantation for hematological malignancies were reported. Among these $\mathrm{CD}$ patients, one become inactive for at least 15 years without any immunosuppressant, and in other CD patients, pathology showed that the disease became inactive (139). Recently, complete normalization of the CD Activity Index (CDAI) was reported after HSC transplantation in two patients with severe, non-responsive, infliximab-resistant CD $(140,141)$. A phase I clinical trial involving refractory CD patients showed clear evidence of recovery after autologous HSC transplantation (142). In another clinical trial on the safety and efficacy of HSC transplantation using autologous adipose tissuederived stem cells (ADSCs) showed complete healing of fistulas in six out of eight patients, 
when a total epithelialization of the external opening was evident (143). Furthermore, it has been shown that allogeneic transplantation of either HSCs or MSCs can populate the injured regions of the colon with similar ability in a TNBS-induced experimental colitis (EC) rat model and that this improved gross morphologic EC scores (144). All of the above studies on HSC transplantation therapy for IBD encourage many scientists to think seriously about this route for long-term disease management. It has been suggested that allogeneic HSC transplantation could prevent and cure IBD and that long-lasting remission can be achieved following autologous HSC transplantation (120).

\section{CONCLUSION AND FUTURE PROSPECTS}

Although increasing evidence suggests that intestinal flora, abnormal immune response, and luminal antigens are involved in the pathogenesis of IBD, to date, no specific bacterial pathogen has been identified as a cause of this disease. The intermittent and aggressive pathological presentation affects the quality of life of these patients. Many agents targeting TNF-alpha, leukocyte adhesion, Th1 polarization, T-cell activation, and CDP571, as well as other therapies, are being evaluated, but the results and effectiveness of these approaches are still in question. The inadequacy of conventional therapy (145) has motivated investigators to develop a novel approach to treat IBD effectively; advances in an alternative approach, such as SC-based therapy, could drive a major change in the lives of these patients.

IBD may be the result of severe cellular infiltrates and is linked with irregularities in the immune system and normal gut flora or an overall autoimmune deregulation in $\mathrm{T}$ cells. The behavior of classical immune cells appears to be deregulated in IBD patients. T lymphocytes and macrophages are considered central effector cells responsible for release of various cytokines, which are responsible in inflammation. Abnormal epithelial and endothelial cell function occurs in the pathogenesis of IBD. It is known that intestinal epithelial cells (IECs) are able to function as nonprofessional APCs and that defective expression of molecules implicated in the expansion of Tregs may cause failure in inhibition of the immune response. Colonic intestinal subepithelial myofibroblasts, juxtaposed with the bottom layer of epithelial cells, play a role in inflammation and wound healing in the intestine. On another note, SCs derived from bone marrow have been shown to differentiate into all of the intestinal lineages and have become invaluable in clinical research. In mouse models and IBD patients treated for coincidental malignancies, bone marrow-derived cells of donor origin contribute to tissue repair in areas of epithelium, endothelium, and myofibroblasts subject to inflammation. Currently, both HSC transplantation and MSC transplantation in IBD patients are under evaluation in phase III clinical trials. Furthermore, reprogrammed induced pluripotent stem cells (iPSc) from fibroblasts, which are functionally equivalent to ESCs, as well as cord-blood derived HSCs and placenta-derived MSCs, could be attractive therapeutic options for IBD. Cellular therapy with SCs is revolutionizing the focus of treatment of many serious diseases, and we hope that combining SC-based therapies with sensible disease management will allow IBD to be easily treated in the near future. Meanwhile, studies seeking to understand the different facets of IBD will eventually lead to the development of new and useful therapies for this disease.

\section{Acknowledgments}

This study was supported in part by grants from NIH P01AT003961.

\section{References}

1. Podolsky DK. Inflammatory bowel disease. N Engl J Med 1991;325:928-937. [PubMed: 1881418] 
2. Sands BE. Inflammatory bowel disease: past, present, and future. J Gastroenterol 2007;42:16-25. [PubMed: 17322989]

3. Xavier RJ, Podolsky DK. Unravelling the pathogenesis of inflammatory bowel disease. Nature 2007;448:427-34. [PubMed: 17653185]

4. Kappelman MD, Rifas-Shiman SL, Kleinman K, Ollendorf D, Bousvaros A, Grand RJ, Finkelstein JA. The prevalence and geographic distribution of Crohn's disease and ulcerative colitis in the United States. Clin Gastroenterol Hepatol 2007;5:1424-9. [PubMed: 17904915]

5. Herrinton LJ, Liu L, Lafata JE, Allison JE, Andrade SE, Korner EJ, Chan KA, Platt R, Hiatt D, O'Connor S. Estimation of the period prevalence of inflammatory bowel disease among nine health plans using computerized diagnoses and outpatient pharmacy dispensings. Inflamm Bowel Dis 2007;13:451-61. [PubMed: 17219403]

6. Loftus EV Jr. The burden of inflammatory bowel disease in the United States: a moving target? Clin Gastroenterol Hepatol 2007;5:1383-4. [PubMed: 18054749]

7. Hay AR, Hay JW. Inflammatory bowel disease: medical cost algorithms. J Clin Gastroenterol 1992;14:318-327. [PubMed: 1607608]

8. Kappelman MD, Rifas-Shiman SL, Porter CQ, Ollendorf D, Sandler RS, Galanko JA, Finkelstein JA. Direct health care costs of Crohn's disease and ulcerative colitis in US children and adults. Gastroenterology 2008;135:1907-13. [PubMed: 18854185]

9. Ananthakrishnan AN, McGinley EL, Binion DG. Inflammatory bowel disease in the elderly is associated with worse outcomes: a national study of hospitalizations. Inflamm Bowel Dis 2009;15:182-9. [PubMed: 18668678]

10. Mizoguchi A, Mizoguchi E. Inflammatory bowel disease, past, present and future: lessons from animal models. J Gastroenterol 2008;43:1-17. [PubMed: 18297430]

11. Kaplan GG, Panaccione R, Hubbard JN, Nguyen GC, Shaheen AA, Ma C, Devlin SM, Leung Y, Myers RP. Inflammatory bowel disease patients who leave hospital against medical advice: predictors and temporal trends. Inflamm Bowel Dis 2009;15:845-51. [PubMed: 19130616]

12. Halfvarson J, Bodin L, Tysk C, Lindberg E, Järnerot G. Inflammatory bowel disease in a Swedish twin cohort: a long-term follow-up of concordance and clinical characteristics. Gastroenterology 2003;124:1767-73. [PubMed: 12806610]

13. Lees CW, Satsangi J. Genetics of inflammatory bowel disease: implications for disease pathogenesis and natural history. Expert Rev Gastroenterol Hepatol 2009;3:513-34. [PubMed: 19817673]

14. Franke A, Balschun T, Karlsen TH, Sventoraityte J, Nikolaus S, Mayr G, Domingues FS, Albrecht M, Nothnagel M, Ellinghaus D, Sina C, Onnie CM, Weersma RK, Stokkers PC, Wijmenga C, Gazouli M, Strachan D, McArdle WL, Vermeire S, Rutgeerts P, Rosenstiel P, Krawczak M, Vatn MH, Mathew CG, Schreiber S. IBSEN study group. Sequence variants in IL10, ARPC2 and multiple other loci contribute to ulcerative colitis susceptibility. Nat Genet 2008;40:1319-23. [PubMed: 18836448]

15. Rodriguez-Bores L, Fonseca GC, Villeda MA, Yamamoto-Furusho JK. Novel genetic markers in inflammatory bowel disease. World J Gastroenterol 2007;13:5560-70. [PubMed: 17948929]

16. Cho JH, Abraham C. Inflammatory bowel disease genetics: Nod2. Annu Rev Med 2007;58:401-16. [PubMed: 16987083]

17. Barrett JC, Hansoul S, Nicolae DL, Cho JH, Duerr RH, Rioux JD, Brant SR, Silverberg MS, Taylor KD, Barmada Bitton MMA, Dassopoulos T, Datta LW, Green T, Griffiths AM, Kistner EO, Murtha MT, Regueiro MD, Rotter JI, Schumm LP, Steinhart AH, Targan SR, Xavier RJ, Libioulle C, Sandor C, Lathrop M, Belaiche J, Dewit O, Gut I, Heath S, Laukens D, Mni M, Rutgeerts P, Van Gossum A, Zelenika D, Franchimont D, Hugot JP, de Vos M, Vermeire S, Louis E, Cardon LR, Anderson CA, Drummond H, Nimmo E, Ahmad T, Prescott NJ, Onnie CM, Fisher SA, Marchini J, Ghori J, Bumpstead S, Gwilliam R, Tremelling M, Deloukas P, Mansfield J, Jewell D, Satsangi J, Mathew CG, Parkes M, Georges M, Daly MJ. NIDDK IBD Genetics Consortium. Genome-wide association defines more than 30 distinct susceptibility loci for Crohn's disease. Nat Genet 2008;40:955-62. [PubMed: 18587394]

18. Zhang HD, Massey M, Tremelling M, Parkes M. Genetics of inflammatory bowel disease: clues to pathogenesis. Br Med Bull 2008;87:17-30. [PubMed: 18753178]

19. Ogura Y, Bonen DK, Inohara N, Nicolae DL, Chen FF, Ramos R, Britton H, Moran T, Karaliuskas R, Duerr RH, Achkar JP, Brant SR, Bayless TM, Kirschner BS, Hanauer SB, Nuez G, Cho JH. A 
frameshift mutation in NOD2 associated with susceptibility to Crohn's disease. Nature 2001;411:603-606. [PubMed: 11385577]

20. Stoll M, Corneliussen B, Costello CM, Waetzig GH, Mellgard B, Koch WA, Rosenstiel P, Albrecht M, Croucher PJ, Seegert D, Nikolaus S, Hampe J, Lengauer T, Pierrou S, Foelsch UR, Mathew CG, Lagerstrom-Fermer M, Schreiber S. Genetic variation in DLG5 is associated with inflammatory bowel disease. Nat Genet 2004;36:476-480. [PubMed: 15107852]

21. Peltekova VD, Wintle RF, Rubin LA, Amos CI, Huang Q, Gu X, Newman B, Van Oene M, Cescon D, Greenberg G, Griffiths AM, St George-Hyslop PH, Siminovitch KA. Functional variants of OCTN cation transporter genes are associated with Crohn disease. Nat Genet 2004;36:471-475. [PubMed: 15107849]

22. Neurath MF, Finotto S, Glimcher LH. The role of Th1/Th2 polarization in mucosal immunity. Nat Med 2002;8:567-573. [PubMed: 12042806]

23. Elphick DA, Mahida YR. Paneth cells: their role in innate immunity and inflammatory disease. Gut 2005;54:1802-1809. [PubMed: 16284290]

24. Abreu MT, Sparrow MP. Translational research in inflammatory bowel disease. Mt Sinai J Med 2006;73:1067-73. [PubMed: 17285196]

25. Van Limbergen J, Russell RK, Nimmo ER, Satsangi J. The genetics of inflammatory bowel disease. Am J Gastroenterol 2007;102:2820-2831. [PubMed: 17894847]

26. Brant SR, Shugart YY. Inflammatory bowel disease gene hunting by linkage analysis: rationale, methodology, and present status of the field. Inflamm Bowel Dis 2004;10:300-311. [PubMed: 15290927]

27. Fuss IJ, Heller F, Boirivant M, Leon F, Yoshida M, Fichtner-Feigl S, Yang Z, Exley M, Kitani A, Blumberg RS, Mannon P, Strober W. Nonclassical CD1d-restricted NK T cells that produce IL-13 characterize an atypical Th2 response in ulcerative colitis. J Clin Invest 2004;113:1490-1497. [PubMed: 15146247]

28. Singh UP, Singh S, Singh R, Cong Y, Taub DD, Lillard JW Jr. Chronic colitis and CXCL10-producing mucosal T helper, NK and NKT cells in IL10-/- mice can be abrogated by CXCL10 blockade. J Interf Cytok Res 2008;28:31-43.

29. Singh UP, Singh S, Venkataraman C, Lillard JW Jr. CXCR3 Axis: Role in Inflammatory Bowel Disease and its Therapeutic Implication. Endocr Metabol Immu Disord: Drug Target 2007;7:111123.

30. Singh UP, Singh S, Singh R, Quinn FD, Potter ME, Lillard JW Jr. Influence of Mycobacterium avium paratuberculosis on colitis development and specifics immune responses during disease. Infec Immun 2007;75:3722-3278. [PubMed: 17502388]

31. Yu QT, Saruta M, Avanesyan A, Fleshner PR, Banham AH, Papadakis KA. Expression and functional characterization of FOXP3+ CD4+ regulatory T cells in ulcerative colitis. Inflamm Bowel Dis 2007;13:191-199. [PubMed: 17206665]

32. Koloski NA, Bret L, Radford-Smith G. Hygiene hypothesis in inflammatory bowel disease: a critical review of the literature. World J Gastroenterol 2008;14:165-73. [PubMed: 18186549]

33. Lanzoni G, Roda G, Belluzzi A, Roda E, Bagnara GP. Inflammatory bowel disease: Moving toward a stem cell-based therapy. World J Gastroenterol 2008;14:4616-26. [PubMed: 18698675]

34. Gionchetti P, Rizzello F, Lammers KM, Morselli C, Sollazzi L, Davies S, Tambasco R, Calabrese C, Campieri M. Antibiotics and probiotics in treatment of inflammatory bowel disease. World $\mathbf{J}$ Gastroenterol 2006;12:3306-13. [PubMed: 16733845]

35. Boden EK, Snapper SB. Regulatory T cells in inflammatory bowel disease. Curr Opin Gastroenterol 2008;24:733-41. [PubMed: 19125486]

36. Sartor RB, Muehlbauer M. Microbial host interactions in IBD: implications for pathogenesis and therapy. Curr Gastroenterol Rep 2007;9:497-507. [PubMed: 18377803]

37. Bank U, Bohr UR, Reinhold D, Lendeckel U, Ansorge S, Malfertheiner P, Tager M. Inflammatory bowel diseases: multiple benefits from therapy with dipeptidyl- and alanyl-aminopeptidase inhibitors. Front Biosci 2008;13:3699-713. [PubMed: 18508466]

38. Zhong W, Kolls JK, Chen H, McAllister F, Oliver PD, Zhang Z. Chemokines orchestrate leukocyte trafficking in inflammatory bowel disease. Front Biosci 2008;13:1654-64. [PubMed: 17981657] 
39. Abraham C, Cho J. Interleukin-23/Th17 pathways and inflammatory bowel disease. Inflamm Bowel Dis 2009;15:1090-100. [PubMed: 19253307]

40. Rosenstiel P, Sina C, Franke A, Schreiber S. Towards a molecular risk map--recent advances on the etiology of inflammatory bowel disease. Semin Immunol 2009;21:334-45. [PubMed: 19926490]

41. Singh SR, Hou SX. Multipotent stem cells in the Malpighian tubules of adult Drosophila melanogaster. J Exp Biol 2009;212:413-23. [PubMed: 19151216]

42. Arthur A, Zannettino A, Gronthos S. The therapeutic applications of multipotential mesenchymal/ stromal stem cells in skeletal tissue repair. J Cell Physiol 2009;218:237-45. [PubMed: 18792913]

43. Kuhn NZ, Tuan RS. Regulation of stemness and stem cell niche of mesenchymal stem cells: implications in tumorigenesis and metastasis. J Cell Physiol 2010;222:268-77. [PubMed: 19847802]

44. Mishra PK, Singh SR, Joshua IG, Tyagi SC. Stem cells as a therapeutic target for diabetes. Front Biosc 2010;15:461-477.

45. Schwartz DA, Maltz BE. Treatment of fistulizing inflammatory bowel disease. Med Clin North Am 2010;94:19-34. [PubMed: 19944796]

46. MacDonald TT, Pettersson S. Bacterial regulation of intestinal immune responses. Infl Bowel Dis 2000;6:116-122.

47. Powrie F, Leach MW. Genetic and spontaneous models of inflammatory bowel disease in rodents: evidence for abnormalities in mucosal immune regulation. Ther Immunol 1995;2:115-123. [PubMed: 8729882]

48. Kuhn R, Lohler J, Rennick D, Rajewsky K, Muller W. Interleukin-10-deficient mice develop chronic enterocolitis. Cell 1993;75:263-274. [PubMed: 8402911]

49. Elson CO, Sartor RB, Tennyson GS, Riddell RH. Experimental models of inflammatory bowel disease. Gastroenterology 1995;109:1344-1367. [PubMed: 7557106]

50. Sadlack B, Merz H, Schorle H, Schimpl A, Feller AC, Horak I. Ulcerative colitis-like disease in mice with a disrupted interleukin-2 gene. Cell 1993;75:253-261. [PubMed: 8402910]

51. Lashner B. Inflammatory bowel disease. Gastroenterology, Current Clinical Medicine Elsevier. 2009

52. Bai A, Lu N, Guo Y, Liu Z, Chen J, Peng Z. All-trans retinoic acid down-regulates inflammatory responses by shifting the Treg/Th17 profile in human ulcerative and murine colitis. J Leukoc Biol 2009;86:959-69. [PubMed: 19477911]

53. Fiocchi C. Inflammatory bowel disease: etiology and pathogenesis. Gastroenterology 1998;115:182205. [PubMed: 9649475]

54. Fuss IJ, Ehrhardt RO, Neurath M, Boirivant M, Ludviksson BR, Strober W. The pathogenesis of mucosal inflammation in murine models of inflammatory bowel disease and Crohn disease. Scand J Immunol 1998;48:453-458. [PubMed: 9822251]

55. Monteleone G. esponse of human intestinal lamina propria T lymphocytes to interleukin additive effects of interleukin 15 and 7. Gut 1998;43:735-736. [PubMed: 9824592]

56. Sundaramoorthi R, Siedem C, Vu CB, Dalgarno DC, Laird EC, Botfield MC, Combs AB, Adams SE, Yuan RW, Weigele M, Narula SS. Selective inhibition of Src SH2 by a novel thiol-targeting tricarbonyl-modified inhibitor and mechanistic analysis by (1)H/(13)C NMR spectroscopy. Bioorg MedChem Lett 2001;11:1665-1669.

57. Cong Y, Konrad A, Iqbal N, Elson CO. Probiotics and immune regulation of inflammatory bowel diseases. Curr Drug Targets Inflamm Allergy 2003;2:145-54. [PubMed: 14561167]

58. Heller F, Florian P, Bojarski C, Richter J, Christ M, Hillenbrand B, Mankertz J, Gitter AH, Bürgel N, Fromm M, Zeitz M, Fuss I, Strober W, Schulzke JD. Interleukin-13 is the key effector Th2 cytokine in ulcerative colitis that affects epithelial tight junctions, apoptosis, and cell restitution. Gastroenterology 2005;129:550-64. [PubMed: 16083712]

59. Monteleone G, Monteleone I, Fina D, Vavassori P, Del Vecchio Blanco G, Caruso R, Tersigni R, Alessandroni L, Biancone L, Naccari GC, MacDonald TT, Pallone F. Interleukin-21 enhances Thelper cell type I signaling and interferon-gamma production in Crohn's disease. Gastroenterology 2005;128:687-94. [PubMed: 15765404]

60. Duerr RH, Taylor KD, Brant SR, Rioux JD, Silverberg MS, Daly MJ, Steinhart AH, Abraham C, Regueiro M, Griffiths A, Dassopoulos T, Bitton A, Yang H, Targan S, Datta LW, Kistner EO, Schumm LP, Lee AT, Gregersen PK, Barmada MM, Rotter JI, Nicolae DL, Cho JH. A genome-wide 
association study identifies IL23R as an inflammatory bowel disease gene. Science 2006;314:14613. [PubMed: 17068223]

61. Duchmann R, Kaiser I, Hermann E, Mayet W, Ewe K, Meyer zum Buschenfelde KH. Tolerance exists towards resident intestinal flora but is broken in active inflammatory bowel disease (IBD). Clin Exp Immunol 1995;102:448-455. [PubMed: 8536356]

62. Nakajima A, Kodama T, Yazaki Y, Takazoe M, Saito N, Suzuki R, Nishino H, Yamamoto K, Silver J, Matsuhashi N. Specific clonal T cell accumulation in intestinal lesions of Crohn's disease. J Immunol 1996;157:5683-5688. [PubMed: 8955222]

63. Probert CS, Chott A, Turner JR, Saubermann LJ, Stevens AC, Bodinaku K, Elson CO, Balk SP, Blumberg RS. Persistent clonal expansions of peripheral blood CD4+ lymphocytes in chronic inflammatory bowel disease. J Immunol 1996;157:3183-3191. [PubMed: 8816432]

64. Maynard CL, Weaver CT. Intestinal effector T cells in health and disease. Immunity 2009;31:389_ 400. [PubMed: 19766082]

65. Kobayashi M, Hoshino H, Masumoto J, Fukushima M, Suzawa K, Kageyama S, Suzuki M, Ohtani H, Fukuda M, Nakayama N. GlcNAc6ST-1-mediated decoration of MAdCAM-1 protein with Lselectin ligand carbohydrates directs disease activity of ulcerative colitis. Inflamm Bowel Dis 2009;15:697-706. [PubMed: 19067429]

66. McGeachy MJ, Chen Y, Tato CM, Laurence A, Joyce-Shaikh B, Blumenschein WM, McClanahan TK, O'Shea JJ, Cua DJ. The interleukin 23 receptor is essential for the terminal differentiation of interleukin 17-producing effector T helper cells in vivo. Nat Immunol 2009;10:314-24. [PubMed: 19182808]

67. Orholm M, Munkholm P, Langholz E, Nielsen OH, Sorensen TI, Binder V. Familial occurrence of inflammatory bowel disease. N Engl J Med 1991;324:84-88. [PubMed: 1984188]

68. Hanauer SB. New steroids for IBD: progress report. Gut 2002;51:182-3. [PubMed: 12117876]

69. Hawthorne AB, Rubin G, Ghosh S. Review article: medication non-adherence in ulcerative colitis-strategies to improve adherence with mesalazine and other maintenance therapies. Aliment Pharmacol Ther 2008;27:1157-66. [PubMed: 18384664]

70. Toruner M, Loftus EV Jr, Harmsen WS, Zinsmeister AR, Orenstein R, Sandborn WJ, Colombel JF, Egan LJ. Risk factors for opportunistic infections in patients with inflammatory bowel disease. Gastroenterology 2008;134:929-36. [PubMed: 18294633]

71. Sandborn WJ, Feagan BG, Lichtenstein GR. Medical management of mild to moderate Crohn's disease: evidence-based treatment algorithms for induction and maintenance of remission. Aliment Pharmacol Ther 2007;26:987-1003. [PubMed: 17877506]

72. Lichtenstein GR, Diamond RH, Wagner CL, Fasanmade AA, Olson AD, Marano CW, Johanns J, Lang Y, Sandborn WJ. Clinical trial: benefits and risks of immunomodulators and maintenance infliximab for IBD-subgroup analyses across four randomized trials. Aliment Pharmacol Ther 2009;30:210-26. [PubMed: 19392858]

73. Nguyen GC, Harris ML, Dassopoulos T. Insights in immunomodulatory therapies for ulcerative colitis and Crohn's disease. Curr Gastroenterol Rep 2006;8:499-505. [PubMed: 17105689]

74. Feagan BG. Maintenance therapy for inflammatory bowel disease. Am J Gastroenterol 2003;98:S6S17. [PubMed: 14697913]

75. Thia KT, Loftus EV Jr, Sandborn WJ, Yang SK. An update on the epidemiology of inflammatory bowel disease in Asia. Am J Gastroenterol 2008;103:3167-82. [PubMed: 19086963]

76. van Dullemen HM, van Deventer SJ, Hommes DW, Bijl HA, Jansen J, Tytgat GN, Woody J. Treatment of Crohn's disease with anti-tumor necrosis factor chimeric monoclonal antibody (cA2). Gastroenterology 1995;109:129-135. [PubMed: 7797011]

77. ten Hove T, van Montfrans C, Peppelenbosch MP, van Deventer SJ. Infliximab treatment induces apoptosis of lamina propria T lymphocytes in Crohn's disease. Gut 2002;50:206-211. [PubMed: 11788561]

78. Breese EJ, Michie CA, Nicholls SW, Murch SH, Williams CB, Domizio P, Walker-Smith JA, MacDonald TT. Tumor necrosis factor alpha-producing cells in the intestinal mucosa of children with inflammatory bowel disease. Gastroenterology 1994;106:1455-1466. [PubMed: 8194690]

79. Reimund JM, Wittersheim C, Dumont S, Muller CD, Kenney JS, Baumann R, Poindron P, Duclos B. Increased production of tumour necrosis factor-alpha interleukin- 1 beta, and interleukin- 6 by 
morphologically normal intestinal biopsies from patients with Crohn's disease. Gut 1996;39:684689. [PubMed: 9026483]

80. Powrie F, Leach MW, Mauze S, Menon S, Caddle LB, Coffman RL. Inhibition of Th1 responses prevents inflammatory bowel disease in scid mice reconstituted with CD45RBhi CD4+ T cells. Immunity 1994;1:553-562. [PubMed: 7600284]

81. Corazza N, Eichenberger S, Eugster HP, Mueller C. Nonlymphocyte-derived tumor necrosis factor is required for induction of colitis in recombination activating gene (RAG)2(-/-) mice upon transfer of CD4(+)CD45RB(hi) T cells. J Exp Med 1999;190:1479-1491. [PubMed: 10562322]

82. Berg DJ, Davidson N, Kuhn R, Muller W, Menon S, Holland G, Thompson-Snipes L, Leach MW, Rennick D. Enterocolitis and colon cancer in interleukin-10-deficient mice are associated with aberrant cytokine production and CD4(+) TH1-like responses. J Clin Invest 1996;98:1010-1020. [PubMed: 8770874]

83. Sandborn WJ. New concepts in anti-tumor necrosis factor therapy for inflammatory bowel disease. Rev Gastroenterol Disord 2005;5:10-8. [PubMed: 15741928]

84. Carpenter HA, Talley NJ. The importance of clinicopathological correlation in the diagnosis of inflammatory conditions of the colon: histological patterns with clinical implications. Am J Gastroenterol 2000;95:878-96. [PubMed: 10763932]

85. Trinchieri G. Interleukin-12: a cytokine produced by antigen-presenting cells with immunoregulatory functions in the generation of T-helper cells type 1 and cytotoxic lymphocytes. Blood 1994;84:40084027. [PubMed: 7994020]

86. Parronchi P, Romagnani P, Annunziato F, Sampognaro S, Becchio A, Giannarini L, Maggi E, Pupilli C, Tonelli F, Romagnani S. Type 1 T-helper cell predominance and interleukin-12 expression in the gut of patients with Crohn's disease. Am J Pathol 1997;150:823-832. [PubMed: 9060820]

87. Ehrhardt RO, Ludviksson BR, Gray B, Neurath M, Strober W. Induction and prevention of colonic inflammation in IL-2-deficient mice. J Immunol 1997;158:566-573. [PubMed: 8992969]

88. Neurath MF, Fuss I, Kelsall BL, Stuber E, Strober W. Antibodies to interleukin 12 abrogate established experimental colitis in mice. J Exp Med 1995;182:1281-1290. [PubMed: 7595199]

89. Rennick DM. MM Fort:Lessons from genetically engineered animal models. XII. IL-10-deficient (IL-10(-/-) mice and intestinal inflammation. Am J Physiol-Gastro \& Liver Physiol 2000;278:G829833.

90. Mannon PJ, Fuss IJ, Mayer L, Elson CO, Sandborn WJ, Present D, Dolin B, Goodman N, Groden C, Hornung RL, Quezado M, Yang Z, Neurath MF, Salfeld J, Veldman GM, Schwertschlag U, Strober W. Anti-IL-12 Crohn's Disease Study Group: Anti-interleukin- 12 antibody for active Crohn's disease. N Engl J Med 2004;351:2069-79. [PubMed: 15537905]

91. Sandborn WJ, Feagan BG, Fedorak RN, Scherl E, Fleisher MR, Katz S, Johanns J, Blank M, Rutgeerts P. Ustekinumab Crohn's Disease Study Group. A randomized trial of Ustekinumab, a human interleukin-12/23 monoclonal antibody, in patients with moderate-to-severe Crohn's disease. Gastroenterology 2008;135:1130-41. [PubMed: 18706417]

92. Elson CO, Cong Y, Weaver CT, Schoeb TR, McClanahan TK, Fick RB, Kastelein RA. Monoclonal anti-interleukin 23 reverses active colitis in a T cell-mediated model in mice. Gastroenterology 2007;132:2359-70. [PubMed: 17570211]

93. Alex P, Zachos NC, Nguyen T, Gonzales L, Chen TE, Conklin LS, Centola M, Li X. Distinct cytokine patterns identified from multiplex profiles of murine DSS and TNBS-induced colitis. Inflamm Bowel Dis 2009;15:341-52. [PubMed: 18942757]

94. Ito R, Kita M, Shin-Ya M, Kishida T, Urano A, Takada R, Sakagami J, Imanishi J, Iwakura Y, Okanoue T, Yoshikawa T, Kataoka K, Mazda O. Involvement of IL-17A in the pathogenesis of DSSinduced colitis in mice. Biochem Biophys Res Commun 2008;377:12-6. [PubMed: 18796297]

95. Ogawa A, Andoh A, Araki Y, Bamba T, Fujiyama Y. Neutralization of interleukin-17 aggravates dextran sulfate sodium-induced colitis in mice. Clin Immunol 2004;110:55-62. [PubMed: 14962796]

96. Plevy S, Salzberg B, Van Assche G, Regueiro M, Hommes D, Sandborn W, Hanauer S, Targan S, Mayer L, Mahadevan U, Frankel M, Lowder J. A phase I study of visilizumab, a humanized antiCD3 monoclonal antibody, in severe steroid-refractory ulcerative colitis. Gastroenterology 2007;133:1414-22. [PubMed: 17920064] 
97. Tao GZ, Strnad P, Zhou Q, Kamal A, Zhang L, Madani ND, Kugathasan S, Brant SR, Cho JH, Omary MB, Duerr RH. Analysis of keratin polypeptides 8 and 19 variants in inflammatory bowel disease. Clin Gastroenterol Hepatol 2007;5:857-64. [PubMed: 17509943]

98. Kamanaka M, Kim ST, Wan YY, Sutterwala FS, Lara-Tejero M, Galá JE, Harhaj E, Flavell RA. Expression of interleukin-10 in intestinal lymphocytes detected by an interleukin-10 reporter knockin tiger mouse. Immunity 2006;25:941-52. [PubMed: 17137799]

99. Perruche S, Zhang P, Liu Y, Saas P, Bluestone JA, Chen W. CD3-specific antibody-induced immune tolerance involves transforming growth factor-beta from phagocytes digesting apoptotic T cells. Nat Med 2008;14:528-35. [PubMed: 18438416]

100. Grimm MC. New and emerging therapies for inflammatory bowel diseases. J Gastroenterol Hepatol 2009;24(S3):S69-74. [PubMed: 19799702]

101. Kelsall BL, Stuber E, Neurath M, Strober W. Interleukin-12 production by dendritic cells. The role of CD40-CD40L interactions in Th1 T-cell responses. Ann NY Acad Sci 1996;795:116-126. [PubMed: 8958922]

102. Mombaerts P, Mizoguchi E, Grusby MJ, Glimcher LH, Bhan AK, Tonegawa S. Spontaneous development of inflammatory bowel disease in T cell receptor mutant mice. Cell 1993;75:274-282. [PubMed: 8104709]

103. Morrissey PJ, Charrier K, Braddy S, Liggitt D, Watson JD. CD4+ T cells that express high levels of CD45RB induce wasting disease when transferred into congenic severe combined immunodeficient mice. Disease development is prevented by cotransfer of purified CD4+ T cells. J Exp Med 1993;178:237-244. [PubMed: 8100269]

104. Matsumoto S, Okabe Y, Setoyama H, Takayama K, Ohtsuka J, Funahashi H, Imaoka A, Okada Y, Umesaki Y. Inflammatory bowel disease-like enteritis and caecitis in a senescence accelerated mouse P1/Yit strain. Gut 1998;43:71-78. [PubMed: 9771408]

105. Bhavsar MD, Amiji MM. Oral IL-10 gene delivery in a microsphere-based formulation for local transfection and therapeutic efficacy in inflammatory bowel disease. Gene Ther 2008;15:1200-9. [PubMed: 18418416]

106. Davidson NJ. The therapeutic potential of anti-cytokine antibodies in the treatment of chronic inflammatory disease. Expert Opin Investig Drugs 1998;7:1115-20.

107. Magram J, Connaughton SE, Warrier RR, Carvajal DM, Wu CY, Ferrante J, Stewart C, Sarmiento U, Faherty DA, Gately MK. IL-12-deficient mice are defective in IFN gamma production and type 1 cytokine responses. Immunity 1996;4:471-81. [PubMed: 8630732]

108. Boushey RP, Yusta B, Drucker DJ. Glucagon-like peptide (GLP)-2 reduces chemotherapyassociated mortality and enhances cell survival in cells expressing a transfected GLP-2 receptor. Cancer Res 2001;61:687-93. [PubMed: 11212269]

109. Hartmann B, Thulesen J, Kissow H, Thulesen S, Orskov C, Ropke C, Poulsen SS, Holst JJ. Dipeptidyl peptidase IV inhibition enhances the intestinotrophic effect of glucagon-like peptide-2 in rats and mice. Endocrinology 2000;141:4013-20. [PubMed: 11089531]

110. Yazbeck R, Howarth GS, Geier MS, Demuth HU, Abbott CA. Inhibiting dipeptidyl peptidase activity partially ameliorates colitis in mice. Front Biosci 2008;13:6850-8. [PubMed: 18508699]

111. Heazlewood CK, Cook MC, Eri R, Price GR, Tauro SB, Taupin D, Thornton DJ, Png CW, Crockford TL, Cornall RJ, Adams R, Kato M, Nelms KA, Hong NA, Florin TH, Goodnow CC, McGuckin MA. Aberrant mucin assembly in mice causes endoplasmic reticulum stress and spontaneous inflammation resembling ulcerative colitis. PLoS Med 2008;5:e54. [PubMed: 18318598]

112. Kang SS, Bloom SM, Norian LA, Geske MJ, Flavell RA, Stappenbeck TS, Allen PM. An antibioticresponsive mouse model of fulminant ulcerative colitis. PLoS Med 2008;5:e41. [PubMed: 18318596]

113. Pousa ID, Maté J, Gisbert JP. Angiogenesis in inflammatory bowel disease. Eur J Clin Invest 2008;38:73-81. [PubMed: 18226040]

114. Thatch KA, Mendelson KG, Haber MM, Schwartz MZ. Growth factor manipulation of intestinal angiogenesis: a possible new paradigm in the management of inflammatory bowel disease. J Surg Res 2009;156:245-9. [PubMed: 19524260]

115. Barker N, van de Wetering M, Clevers H. The intestinal stem cell. Genes Dev 2008;22:1856-64. [PubMed: 18628392] 
116. van der Flier LG, Clevers H. Stem cells, self-renewal, and differentiation in the intestinal epithelium. Annu Rev Physiol 2009;71:241-60. [PubMed: 18808327]

117. Wang P, Hou SX. Regulation of intestinal stem cells in mammals and Drosophila. J Cell Physiol 2010;222:33-7. [PubMed: 19739102]

118. Wright NA. Epithelial stem cell repertoire in the gut: clues to the origin of cell lineages, proliferative units and cancer. Int J Exp Pathol 2000;81:117-143. [PubMed: 10762441]

119. Singh SR, Hou SX. Lessons learned about adult kidney stem cells from the malpighian tubules of Drosophila. J Am Soc Nephrol 2008;19:660-6. [PubMed: 18287558]

120. Brittan M, Alison MR, Schier S, Wright NA. Bone marrow stem cell-mediated regeneration in IBD: where do we go from here? Gastroenterology 2007;132:1171-3. [PubMed: 17383436]

121. Powell DW, Mifflin RC, Valentich JD, Crowe SE, Saada JI, West AB. Myofibroblasts. II. Intestinal subepithelial myofibroblasts. Am J Physiol 1999;277:183-201.

122. Otte JM, Rosenberg IM, Podolsky DK. Intestinal myofibroblasts in innate immune responses of the intestine. Gastroenterology 2003;124:1866-1878. [PubMed: 12806620]

123. Saada JI, Barrera CA, Reyes VE, Adegboyega PA, Suarez G, Tamerisa RA, Pang KF, Bland DA, Mifflin RC, DIM JF, Powell DW. Intestinal myofibroblasts and immune tolerance. Ann N Y Acad Sci 2004;1029:379-381. [PubMed: 15681786]

124. Andoh A, Fujino S, Okuno T, Fujiyama Y, Bamba T. Intestinal subepithelial myofibroblasts in inflammatory bowel diseases. Gastroenterol 2002;37:33-7.

125. Gordon JN, Pickard KM, Di Sabatino A, Prothero JD, Pender SL, Goggin PM, MacDonald TT. Matrix metalloproteinase-3 production by gut IgG plasma cells in chronic inflammatory bowel disease. Inflamm Bowel Dis 2008;14:195-203. [PubMed: 18022869]

126. Beyth S, Borovsky Z, Mevorach D, Liebergall M, Gazit Z, Aslan H, Galun E, Rachmilewitz J. Human mesenchymal stem cells alter antigen-presenting cell maturation and induce T-cell unresponsiveness. Blood 2005;105:2214-9. [PubMed: 15514012]

127. González MA, Gonzalez-Rey E, Rico L, Büscher D, Delgado M. Adipose-derived mesenchymal stem cells alleviate experimental colitis by inhibiting inflammatory and autoimmune responses. Gastroenterology 2009;136:978-89. [PubMed: 19135996]

128. Uccelli A, Moretta L, Pistoia V. Mesenchymal stem cells in health and disease. Nat Rev Immunol 2008;8:726-36. [PubMed: 19172693]

129. Panés J, Salas A. Mechanisms underlying the beneficial effects of stem cell therapies for inflammatory bowel diseases. Gut 2009;58:898-900. [PubMed: 19520885]

130. Lanzoni G, Alviano F, Marchionni C, Bonsi L, Costa R, Foroni L, Roda G, Belluzzi A, Caponi A, Ricci F, Tazzari PL, Pagliaro P, Rizzo R, Lanza F, Baricordi OR, Pasquinelli G, Roda E, Bagnara GP. Isolation of stem cell populations with trophic and immunoregulatory functions from human intestinal tissues: potential for cell therapy in inflammatory bowel disease. Cytotherapy 2009;11:1020-3. [PubMed: 19929466]

131. Schmeisser A, Strasser RH. Phenotypic overlap between hematopoietic cells with suggested angioblastic potential and vascular endothelial cells. J Hematother Stem Cell Res 2002;11:69-79. [PubMed: 11847004]

132. McCarroll SA, Bradner JE, Turpeinen H, Volin L, Martin PJ, Chilewski SD, Antin JH, Lee SJ, Ruutu T, Storer B, Warren EH, Zhang B, Zhao LP, Ginsburg D, Soiffer RJ, Partanen J, Hansen JA, Ritz J, Palotie A, Altshuler D. Donor-recipient mismatch for common gene deletion polymorphisms in graft-versus-host disease. Nat Genet 2009;41:1341-4. [PubMed: 19935662]

133. Chamberlain G, Fox J, Ashton B, Middleton J. Concise review: mesenchymal stem cells: their phenotype, differentiation capacity, immunological features, and potential for homing. Stem Cells 2007;25:2739-49. [PubMed: 17656645]

134. Murry CE, Keller G. Differentiation of embryonic stem cells to clinically relevant populations: lessons from embryonic development. Cell 2008;132:661-80. [PubMed: 18295582]

135. Srivastava AS, Feng Z, Mishra R, Malhotra R, Kim HS, Carrier E. Embryonic stem cells ameliorate piroxicam-induced colitis in IL10-/- KO mice. Biochem Biophys Res Commun 2007;361:953-9. [PubMed: 17692287] 
136. Zhang Q, Shi S, Liu Y, Uyanne J, Shi Y, Shi S, Le AD. Mesenchymal stem cells derived from human gingiva are capable of immunomodulatory functions and ameliorate inflammation-related tissue destruction in experimental colitis. J Immunol 2009;183:7787-98. [PubMed: 19923445]

137. Drakos PE, Nagler A, Or R. Case of Crohn's disease in bone marrow transplantation. Am J Hematol 1993;43:57-158. [PubMed: 8317465]

138. Snowden JA, Brooks PM, Biggs JC. Haemopoietic stem cell transplantation for autoimmune diseases. Br J Haematol 1997;99:9-22. [PubMed: 9359496]

139. Lopez-Cubero SO, Sullivan KM, McDonald GB. Course of Crohn's disease after allogeneic marrow transplantation. Gastroenterology 1998;114:433-440. [PubMed: 9496932]

140. Craig RM, Traynor A, Oyama Y, Burt RK. Hematopoietic stem cell transplantation for severe Crohn's disease. Bone Marrow Transplant 2003;32:57-59. [PubMed: 12815479]

141. Burt RK, Traynor A, Oyama Y, Craig R. High-dose immune suppression and autologous hematopoietic stem cell transplantation in refractory Crohn disease. Blood 2003;101:2064-2066. [PubMed: 12393477]

142. Oyama Y, Craig RM, Traynor AE, Quigley K, Statkute L, Halverson A, Brush M, Verda L, Kowalska B, Krosnjar N, Kletzel M, Whitington PF, Burt RK. Autologous hematopoietic stem cell transplantation in patients with refractory Crohn's disease. Gastroenterology 2005;128:552-563. [PubMed: 15765390]

143. Garcia-Olmo D, Garcia-Arranz M, Herreros D, Pascual I, Peiro C, Rodriguez-Montes JA. A phase I clinical trial of the treatment of Crohn's fistula by adipose mesenchymal stem cell transplantation. Dis Colon Rectum 2005;48:1416-1423. [PubMed: 15933795]

144. Wei Y, Nie Y, Lai J, Wan YJ, Li Y. Comparison of the population capacity of hematopoietic and mesenchymal stem cells in experimental colitis rat model. Transplantation 2009;88:42-8. [PubMed: 19584679]

145. Sandborn WJ, Targarn SR. Biologic therapy of inflammatory bowel disease. Gastroenterol 2002;122:1592-1608.

\section{Abbreviations}

$\begin{array}{ll}\text { APC } & \text { antigen presenting cell } \\ \text { CD } & \text { Crohns disease } \\ \text { CDAI } & \text { Chrohn's Disease activity index } \\ \text { DC } & \text { dendritic cell } \\ \text { ESCs: DP } & \text { dipeptidyl peptidase, embryonic stem cells } \\ \text { ER } & \text { endoplasmic reticulum } \\ \text { EC } & \text { experimental colitis } \\ \text { GLP } & \text { glucagon-like peptide } \\ \text { GMSCs } & \text { gingival-derived MSCs } \\ \text { hASCs } & \text { human adult stem cells } \\ \text { HDACs } & \text { histone/protein deacetylase inhibitors } \\ \text { HSCs } & \text { hematopoietic stem cells } \\ \text { IFN } & \text { interferon } \\ \text { IL } & \text { interleukin } \\ \text { IECs } & \text { intestinal epithelial cells } \\ \text { iPSc } & \text { induced pluripotent stem cells } \\ \text { LP } & \text { lamina propria }\end{array}$




$\begin{array}{ll}\text { MMP } & \text { matrix metalloproteinase } \\ \text { MSCs } & \text { mesenchymal stem cells } \\ \text { NK } & \text { natural killer } \\ \text { SCs } & \text { stem cells } \\ \text { SCID } & \text { severe-combined immuno-deficient } \\ \text { TCR } & \text { T cell receptor } \\ \text { TD } & \text { terminally differentiated } \\ \text { TNBS } & \text { 2,4,6-trinitrobenzene sulfonic acid } \\ \text { Treg } & \text { regulatory T cell } \\ \text { TGF } & \text { transforming growth factor } \\ \text { Th-1 } & \text { type 1 helper T cells } \\ \text { Th-2 } & \text { type 2 helper T cells } \\ \text { TIMPs } & \text { tissue inhibitor of metalloproteinases } \\ \text { TNF } & \text { tumour necrosis factor }\end{array}$

Front Biosci (Schol Ed). Author manuscript; available in PMC 2011 January 1. 
A. Crohn's disease

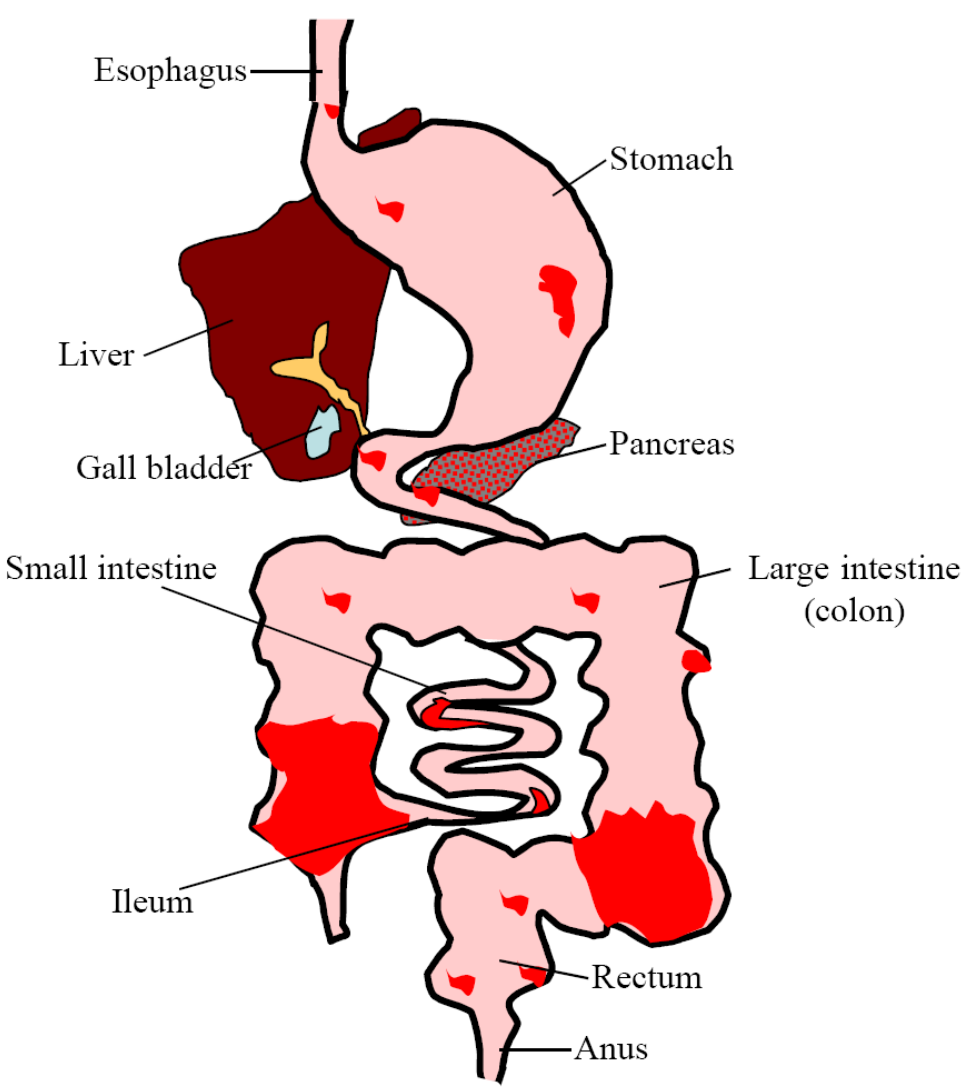

B. Ulcerative colitis

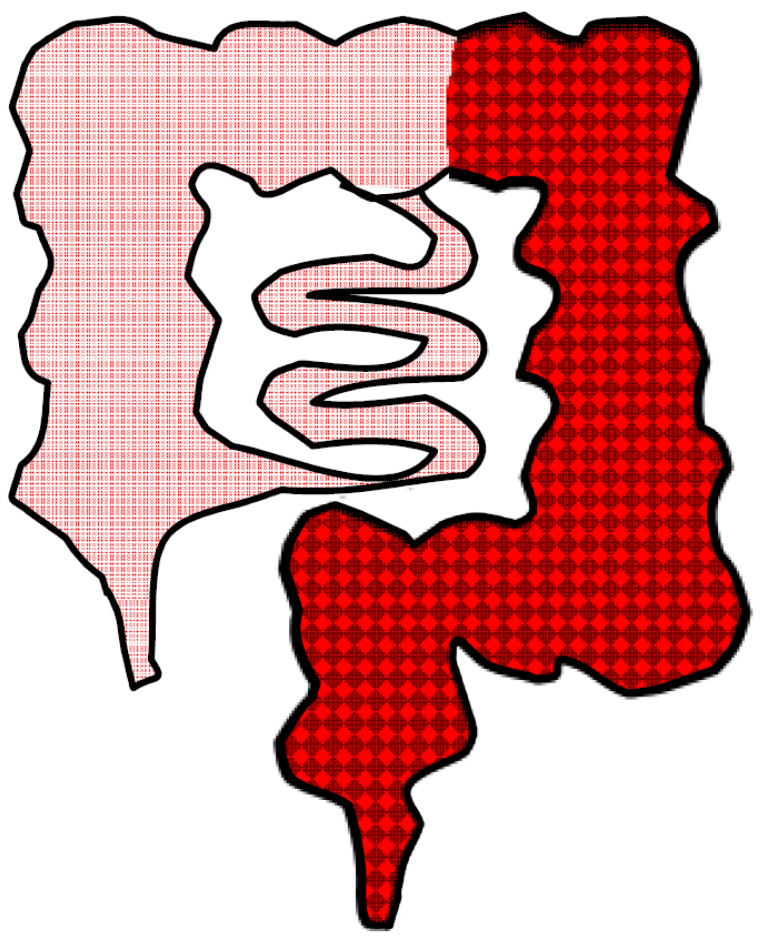

Figure 1.

Inflammatory Bowel disease. (A) Crohn's disease (CD): in which the inflammation of the entire digestive tract, from mouth to anus. The inflammatory processes appear mostly in the lower part of the small intestine. (B) Ulcerative colitis (UC): the inflammation is limited to the area of the colon. 


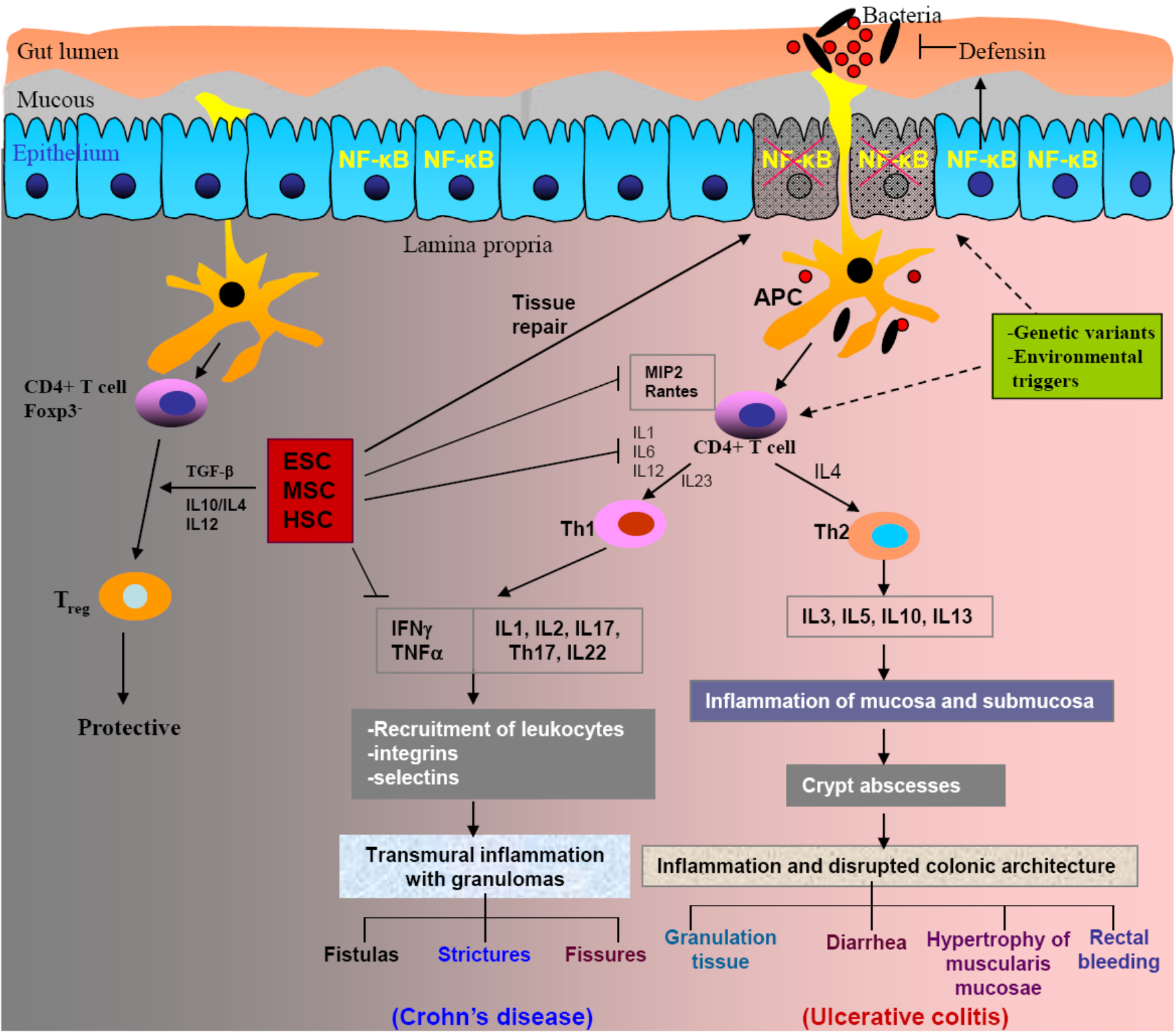

Figure 2.

Stem cells in Inflammatory Bowel disease. 
Table 1

Distinguishing features of ulcerative colitis versus Crohn's disease

\begin{tabular}{|c|c|c|}
\hline Features & CD & UC \\
\hline Anatomic location & Skip & Continuous \\
\hline Site of disease & Any part of GI tract & Colon only \\
\hline Age & $20-30,40-50$ & $20-40$ \\
\hline Gender & No gender preference & Male predilection \\
\hline Bleeding & Absent & Common \\
\hline Etiology & Possibly autoimmune & Not known \\
\hline Abscesses & Common & Rare \\
\hline Fissuring & Common & Rare \\
\hline Fibrosis & Common & Rare \\
\hline Fistulas & Common & Rare \\
\hline Submucosal inflammation & Common & Rare \\
\hline Small bowel involvement & Common & Rare \\
\hline Colon involvement & Usually & Always \\
\hline Rectal involvement & $20 \%$ & $100 \%$ \\
\hline Terminal Ileum involvement & Common & Rare \\
\hline Perianal involvement & Common & Rare \\
\hline Wall thickening & Yes & Yes \\
\hline Increased wall enhancement & Yes & Yes \\
\hline Mucosal inflammation & Deep & Shallow \\
\hline Cobblestoning of mucosa & Common & Rare \\
\hline Submucosal inflammation & Yes & No \\
\hline Mucosal friability & Rare & Common \\
\hline Vascular pattern & Normal & Absent \\
\hline Fat wrapping & Common & Rare \\
\hline Strictures & Common & Rare \\
\hline Sirositis & Yes & No \\
\hline Neuronal Hyperplasia & Yes & No \\
\hline Risk associated with smoking & High & Low \\
\hline Surgical cure & Never & Possible \\
\hline Cytokine response & Associated with $\mathrm{Th} 1, \mathrm{~T}_{\mathrm{h}} 17$ & Associated with $T_{h} 2$ \\
\hline Colorectal cancer risk & Less & More common \\
\hline
\end{tabular}


Table 2

New therapies in development or clinical evaluation for the treatment of IBD

\begin{tabular}{|c|c|c|}
\hline Target of drugs developed cell subset & Company & Disease \\
\hline \multicolumn{3}{|l|}{ Th1/Th2 } \\
\hline Anti-interferon-gamma Ab & Protein Design Lab & $\mathrm{CD}$ \\
\hline Anti-interleukin-2 receptor $\mathrm{Ab}$ & Protein Design Lab & $\mathrm{UC}$ \\
\hline Anti-interleukin-12 Ab & Genetics Institute & $\mathrm{CD}$ \\
\hline Interleukin 10 & Schering Plough & $\mathrm{CD}$ \\
\hline \multicolumn{3}{|l|}{ Leukocytes Adhesion } \\
\hline Anti-alpha4 integrin $\mathrm{Ab}$ (natalizumab) & Elan \& Biogen Pharma. & $\mathrm{CD} \& \mathrm{UC}$ \\
\hline Anti-alpha4beta7 integrin Ab (LDP-2) & Millennium Pharma. & $\mathrm{CD} \& \mathrm{UC}$ \\
\hline \multicolumn{3}{|l|}{ TNF-alpha mediated } \\
\hline Chimeric Anti-TNF-factor Ab (infliximab) & Centocor \& Schering plough & $\mathrm{CD} \& \mathrm{UC}$ \\
\hline Humanized Anti-TNF-factor Ab (CDP571) & Celltech & $\mathrm{CD} \& \mathrm{UC}$ \\
\hline TNF-factor receptor fusion protein (etanercept) & Immunex & $\mathrm{CD}$ \\
\hline $\mathrm{P}^{55} \mathrm{TNF}-$ factor binding protein (onercept) & Serono & $\mathrm{CD}$ \\
\hline CNI-1493 (MAP-kinase inhibitor) & Cytokine pharma Science & $\mathrm{CD}$ \\
\hline Thalidomide & Cellgene & $\mathrm{CD}$ \\
\hline CBP-1011 (TNF-alpha antagonist/IL-6 antagonist) & InKine Pharmaceutical Co & $\mathrm{CD}$ \\
\hline Adalimumab (Anti-TNF-alpha MAb) & Abbott & $\mathrm{UC}$ \\
\hline \multicolumn{3}{|l|}{ Leukocyte Activation } \\
\hline Granulocyte macrophage stimulating factor & Immunex & $\mathrm{CD}$ \\
\hline Epidermal growth factor & CIBG & $\mathrm{UC}$ \\
\hline Keratinocyte growth factor (repifermin) & Human Genome Science & $\mathrm{UC}$ \\
\hline Interleukin-11 & Genetics Institute & $\mathrm{CD}$ \\
\hline Anti-CD40 ligand Ab & IDEC Pharma & $\mathrm{CD}$ \\
\hline \multicolumn{3}{|l|}{ Anti-inflammatory cytokine } \\
\hline AG011 (Interleukin-10) & Actozenix & $\mathrm{CD} \& \mathrm{UC}$ \\
\hline \multicolumn{3}{|l|}{ CXCR3 axis } \\
\hline CXCR3 antagonist (T487) & Tularik and Chemo Centryx & Psoriasis \& Rheumatoid arthritis \\
\hline CXCR3 antagonist (NBI-74330) & Neurocrine Biosciences & $?$ \\
\hline Anti-CXCL10 antibody & Medarex & $\mathrm{UC}$ \\
\hline Anti-CXCL10 antibody & Protein Design Labs & $\mathrm{CD}$ \\
\hline
\end{tabular}

Modified after Sandborn \& Targarn (145) 